\title{
Long-term assessment of creep and water effects on tunnel lining loads in weak rocks using displacement-based direct back analysis: an example from northwest of Iran
}

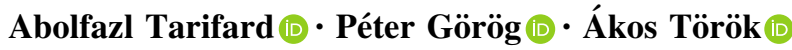

Received: 2 July 2021 / Accepted: 3 January 2022/Published online: 18 January 2022

(C) The Author(s) 2022

\begin{abstract}
The time-dependent stability of tunnels is an important and challenging topic, mainly when the tunnel is excavated in incompetent and weak rocks. The creep property of rock is one of the crucial mechanical properties of weak rock and the main factor affecting the long-term stability of rock masses. Also, water as an important environmental factor influences both the short-term and long-term behavior of rocks and is one of the causes of geotechnical engineering disasters, such as tunnel collapse, slope sliding, surface subsidence, etc. In this research, the effects of rock's creep behavior and underground water on the long-term stability of the Shibli tunnels were analyzed. Geological maps and reports of Shibli tunnels show a highly jointed condition in the surrounding rocks which have been crushed by two orogenic stages. The Burger-creep visco-plastic model was used to simulate the tunnel host rock creep behavior. The model's parameters were adopted based on the displacement-based direct back analysis technique using a univariate optimization algorithm. In addition, the influence of underground water is assessed under the condition of the varying water table. Support capability diagrams were used to evaluate the loading created on the tunnel's permanent
\end{abstract}

A. Tarifard $(\bowtie) \cdot P$. Görög · Á. Török

Department of Engineering Geology and Geotechnics,

Budapest University of Technology and Economics,

Múegyetem rkp. 3, Budapest 1111, Hungary

e-mail: abolfazl.tarifard.karvigh@emk.bme.hu lining due to the creep behavior of rock mass and underground water. This study suggests that the weak rock's creep behavior and underground water significantly affect the time-dependent stability of tunnels. Results show that the induced stresses due to the rock's creep behavior and underground water are more considerable in the tunnel spring-line. Also, the increasing $20 \mathrm{~m}$ in the water table approximately decreases ten years of tunnel lining stability time at the fault zone.

\section{Article highlights}

- Rocks creep behavior and underground water significantly affect the time-dependent stability of tunnels in weak rocks.

- Displacement-based direct back analysis using a univariate optimization algorithm was used to determine the CVISC model's properties.

- Increasing $20 \mathrm{~m}$ in the water table approximately decreases ten years of tunnel lining stability time at the fault zone.

Keywords Tunnel · Weak rock mass · Creep · Underground water $\cdot$ Back analysis $\cdot$ Numerical modeling 


\section{Introduction}

The long-term behavior and stability of rock engineering structures such as tunnels have received considerable attention (Jia et al. 2020; Do et al. 2020; Sharifzadeh and Tarifard 2014; Pellet et al. 2009). A significant number of engineering applications and laboratory studies indicated the mechanical response related to weak and soft rock's time-dependent behavior is relatively complicated (Zhu et al. 2020; Yan et al. 2020; Török et al. 2019; Singh et al. 2018; Patil et al. 2018; Vlastelica et al. 2018; Lyu et al. 2017; Günther et al. 2015; Miščević and Vlastelica 2014; Zhou et al. 2014). One of the significant parameters affecting the underground spaces' longterm stability is weak rock mass creep response (Kovačević et al. 2021; Panthi and Shrestha 2018). In addition, underground water as an important environmental component influences weak rock's short-term and long-term behavior, especially in fault and karst regions (Verbovšek and Kanduč 2016).

In previous studies, some vital researches have been conducted on underground construction's time-dependent behavior. For the long-term study of underground spaces, most researchers focused on the creep behavior of rocks and proposed several valuable creep constitutive models (Wang and Cai 2020; Bérest et al. 2019; Sharifzadeh et al. 2013; Weng et al. 2010; Schenk et al. 2006; Pellet et al. 2005; Grgic et al. 2003). Recently, some researchers have assessed the time-dependent stability of the tunnel's permanent lining. Xu et al (2019) investigated the weak rocks creep behavior on the failure process of the final lining of the Dujia tunnel. Xu and Gutierrez (2021) studied the damage evolution of the final tunnel lining under the combined effects of corrosion of the temporary support and the creep behavior of the surrounding rock. Before the last decade, most of the suggested constitutive models focused on the first and second phase of rock creep, but in the previous decade, some researches were conducted on the numerical modeling of the third phase of rock creep (Liu et al. 2021; Zhang et al. 2020a; Wang et al. 2017; Sainoki et al. 2017; Haifeng and Zhigen 2016; Yang et al. 2015; Xu et al. 2012). Some researchers also simultaneously examine the effects of water and creep on a laboratory scale (Jia et al. 2018; Schenk et al. 2006).

Some experimental studies have shown that the water considerably impacts the weak rocks' creep behavior (Yu et al. 2015; Schenk et al. 2006; Hoxha et al. 2006). Hoxha et al. (2006) found that the creep strain rate in triaxial and uniaxial compression creep tests was substantially dependent on the relative humidity.

Most of the practical rock mechanics projects in the humidity region, such as tunnels, are constructed in dry or relatively dry conditions due to tunnel drainage and ventilation, but in this kind of underground space, the underground water level may be gradually increased during the tunnel service life. Therefore, a detailed evaluation of the creep behavior of rock under various underground water tables is essential to understand the time-dependent stability of the underground constructions.

Our research analyses the effect of rock mass creep behavior and underground water on the time-dependent stability of the Shibli tunnels. The surrounding rocks of the tunnels are mainly marl, calcareous shale, and gray to black shale. Our research concentrates on the part of the northern tunnel near faults 9 and 10 (Fig. 2) in which the host rock is highly fractured, and there was a water rush during tunnel construction (Fig. 4a) (Aradan Construction Co. 2009). In this paper, the CVISC model was selected to analyze the rock mass's creep behavior, and the tunnel behavior was assessed in terms of increasing underground water tables. The direct back analysis was used to adopt model parameters. After analyzing creep and underground water effects, the time-dependent stability of tunnel lining was examined.

\section{Characteristics of Shibli tunnels}

The Shibli tunnels were excavated in the westnorthern area of the central Iran geological formation. These tunnels as parts of the Tabriz-Zanjan highway connect Tabriz and Bostanabad. (Fig. 1). For the elimination of heavy traffic, the northern tunnel with a length of $2244 \mathrm{~m}$ and the southern tunnel with a length of $2289 \mathrm{~m}$ have been excavated. The Shibli tunnels' surrounding rocks mainly consist of marl, limestone, calcareous shale, and gray to black shale, that significantly crushed by two orogenic stages (Fig. 2). Based on the engineering geology studies, the tunnels' surrounding rocks were categorized in $\mathrm{A}, \mathrm{B}$, and $\mathrm{C}$ blocks (Aradan Construction Co. 2009). Block A, consisting of calcareous and sandy shale, is the most 


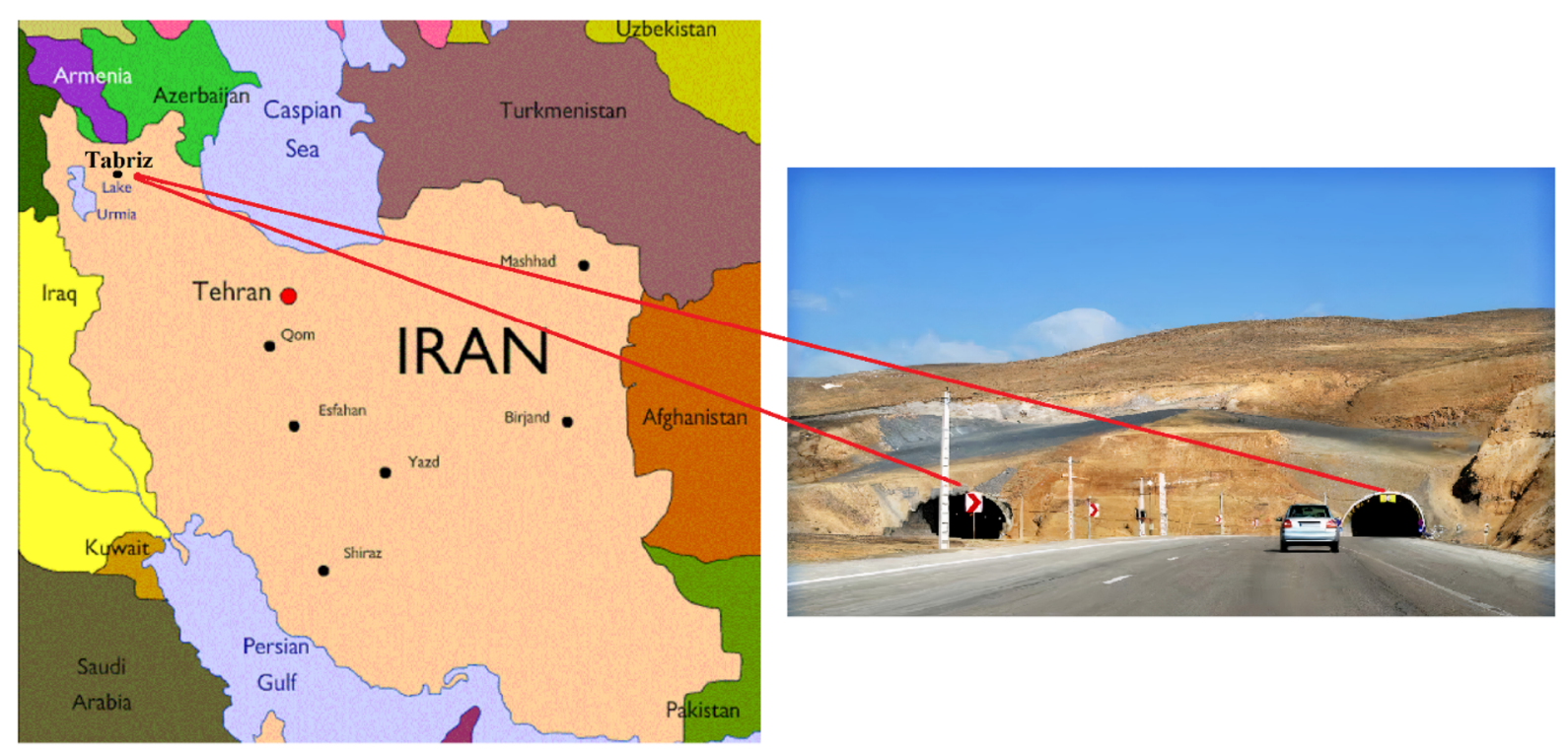

Fig. 1 The position of case study in the northwest of Iran

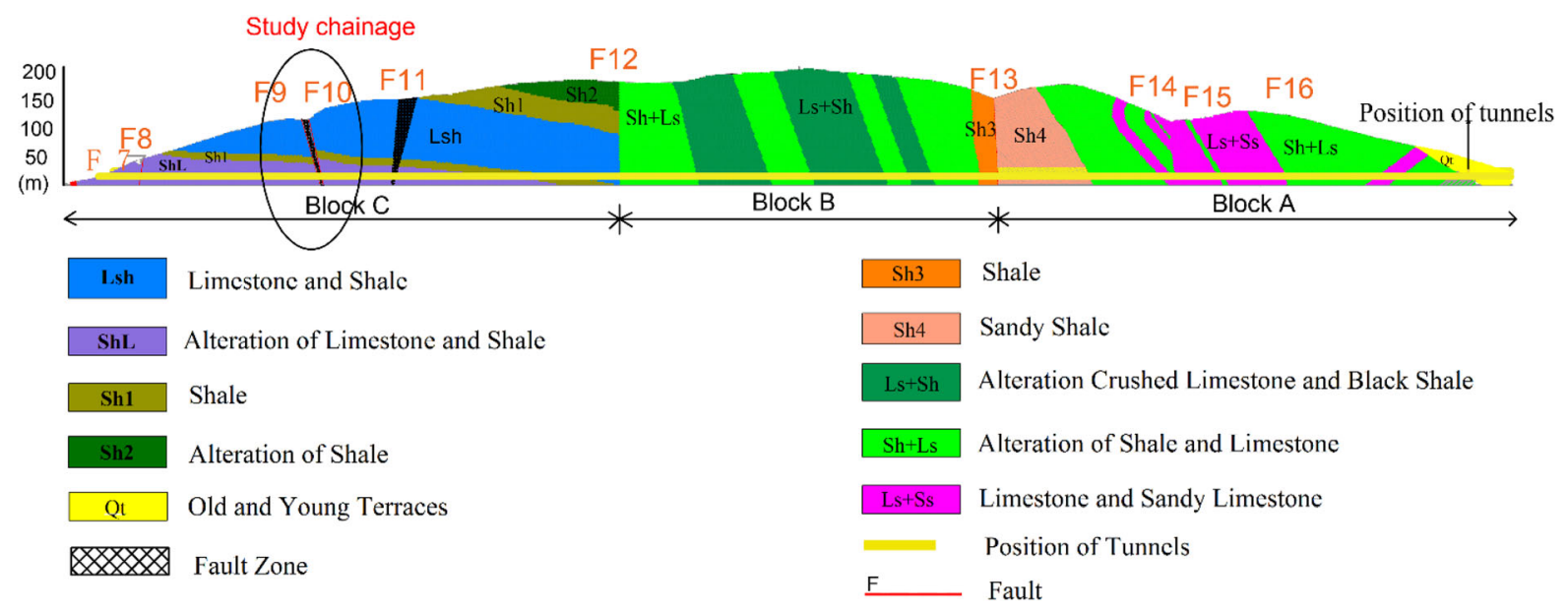

Fig. 2 Longitudinal section and geological parts of Shibli tunnels

competent region of the tunnel's surrounding rocks. Block B is made up of gray to black shale and jointed limestone, and its RMR index is associated with the fair class. Furthermore, block C's host rocks include crushed black shale and marl (Sharifzadeh et al. 2013). Block $\mathrm{C}$ contains the poorest rocks that initiate the most challenging circumstances, particularly where high-water inflows and heavily tectonized zones coincide. Twelve small fault zones with a Northwest-Southeast strike deviate from the Tabriz fault pass through the Shibli tunnels. The northern and southern tunnels have maximum rock cover thicknesses of 180 and $188 \mathrm{~m}$, respectively.

Rock mass classification methods like RMR, Q, and GSI were used to identify the rock mass's quality. Table 1 shows detailed information on rock mass rating. (Sharifzadeh et al. 2013, 2012; Aradan Construction Co. 2009).

In Table 1, the UCS tests were conducted on ovendry conditions. As the most incompetent rock, the host rock of block $\mathrm{C}$ is mainly composed of crushed black shale. Based on previous researches, the softening coefficient for shale could be in various ranges. For 
Table 1 Geomechanical properties

\begin{tabular}{lllllllll}
\hline Block & RMR & GSI & Q & UCS (MPa) & C (kPa) & E (GPa) & $\boldsymbol{\varphi}\left({ }^{\circ}\right)$ & $\gamma\left(\boldsymbol{g} / \mathbf{c m}^{3}\right)$ \\
\hline A & $47-53$ & $45-52$ & $1.1-1.4$ & $44-49$ & 358 & 2.35 & 37 & 2.36 \\
B & $42-47$ & $36-42$ & $0.7-0.9$ & $41-46$ & 337 & 2.1 & 33 & 2.33 \\
C & $35-41$ & $30-35$ & $0.4-0.6$ & $33-39$ & 320 & 1.93 & 30 & 2.2 \\
\hline
\end{tabular}

example, Li et al (2020) measured the softening coefficient equal to 0.52 in the condition of triaxial compression, and Guo et al (2012) calculated it as 0.78. A top-heading and benching approach was used to excavate the Shibli tunnels. Both tunnel crosssections are horseshoe-shaped, the width of the tunnels is $13.26 \mathrm{~m}$, and their height is $10.5 \mathrm{~m}$. In block C, the initial support system involves six meters of grouted rock bolts, shotcrete with a thickness of $25 \mathrm{~cm}$, and steel rib with $50 \mathrm{~cm}$ spacing, which were placed after each tunneling sequence. The permanent lining with a thickness of $40 \mathrm{~cm}$ was installed one year after topheading excavation. Figure 3 shows the tunnel's cross-section, and Table 2 lists the proprieties of the temporary and permanent lining system.
Ground movement monitoring is necessary during tunnel building to ensure construction safety and obtain crucial data for back analysis. Instrumentation was used to monitor the deformations of the Shibli tunnels. Three convergence measurement stations were placed following an excavation of tunnel's upper part to monitor tunnel deformations. The array was extended to offer five-point convergence measurements with bench tunneling. Furthermore, three-point borehole extensometers were placed and recorded. (Sharifzadeh 2012).
Fig. 3 Cross-section of Shibli tunnel

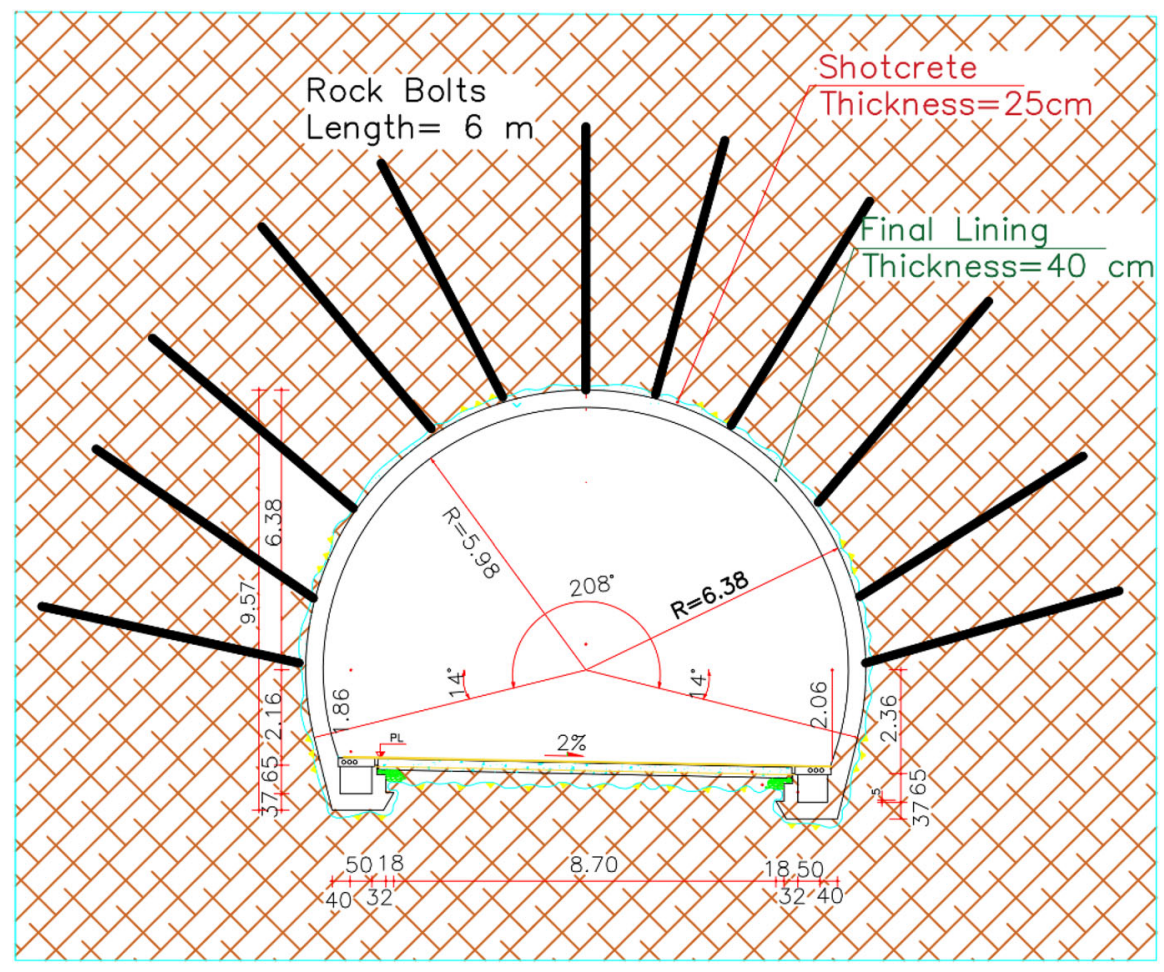

Crushed Black Shale 
Table 2 Initial and final support system

\begin{tabular}{|c|c|c|c|c|c|}
\hline \multirow[t]{2}{*}{ Block } & \multirow[t]{2}{*}{ Final lining } & \multicolumn{4}{|l|}{ Initial supports } \\
\hline & & Steel rib & Shotcrete & Rock bolt & Welded wire mesh \\
\hline A & $40 \mathrm{~cm}$ & IPE180@100 cm & $25 \mathrm{~cm}$ & $\varnothing 25,60 \mathrm{~cm} @ 100 \times 100 \mathrm{~cm}$ & $\varnothing 6 @ 100 \times 100$ \\
\hline B & & IPE180@100 cm & & $\varnothing 25,60 \mathrm{~cm} @ 100 \times 100 \mathrm{~cm}$ & $\varnothing 6 @ 100 \times 100$ \\
\hline $\mathrm{C}$ & & IPE180@50 cm & & $\varnothing 25,60 \mathrm{~cm} @ 100 \times 100 \mathrm{~cm}$ & $\varnothing 6 @ 100 \times 100$ \\
\hline
\end{tabular}

\section{Numerical modeling}

The FLAC software was employed for time-dependent numerical modeling. (Itasca Consulting Group 2002). The research analyzes the long-term stability of the northern tunnel at chainage $27+210$. In this station, the lithology is composed of strongly jointed and crushed shale; four joint sets were measured, and the average spacing between joints was measured $60 \mathrm{~mm}$ (Aradan Construction Co. 2009). During tunnel construction in this location, due to faults 9 and 10 (Fig. 2), water inrushed into the tunnel and created some difficulties in tunnel construction (Fig. 4a) (Aradan Construction Co. 2009). In addition, high precipitation levels in areas near the tunnel (Fig. 4b) increase the possibility of underground water rise, especially in fault and karst regions. Figure 5 depicts the finite-difference grid used for this cross-section. The model's dimensions were selected greater than ten times the tunnel's span to reduce boundary impacts. Element sizes and aspect ratios are refined and gradually rise outwards near the tunnel wall.

\subsection{Creep modeling}

The CVISC model was adopted to assess the creep response of the tunnel's surrounding weak rock (Itasca Consulting Group 2002). Figure 6a represents the elasto-plastic volumetric behavior, and Fig. $6 \mathrm{~b}$ describes the visco-elasto-plastic deviatoric behavior of this model. The Burger model refers to the viscoelastic constitutive law. The Mohr-Coulomb (MC) model refers to the plastic constitutive law that pseudo-simulates the creep's third phase. Because the plastic slider is not connected to a viscous dashpot, plastic yielding is not time-dependent and only depends on the stress. If the model is stressed above the slider's yielding stress, it behaves like an elastoplastic material. In contrast, if the model is stressed under the yielding threshold, it acts like the Burger body (Kabwe et al. 2020a).
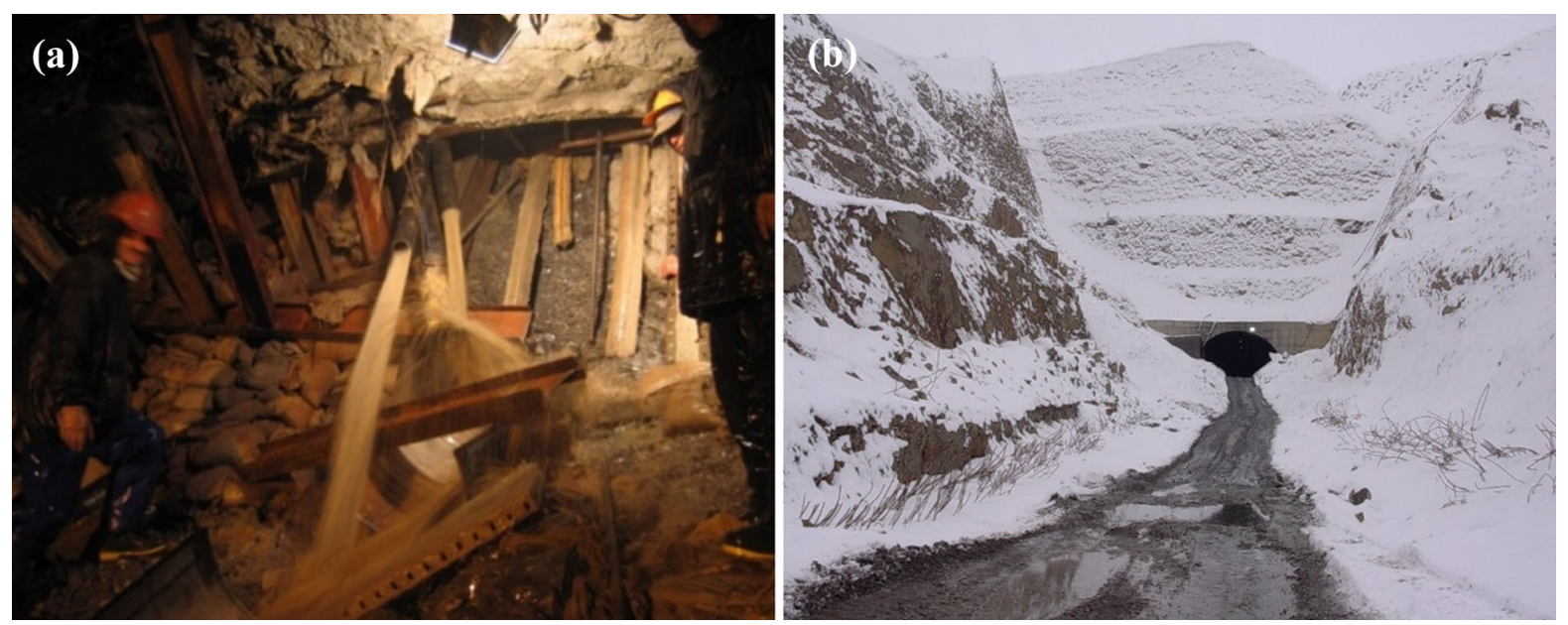

Fig. 4 a Difficulties in tunnel construction due to water adjacent faults 9 and $10 \mathbf{b}$ high precipitation levels in areas near the tunnel 
Fig. 5 A numerical model for the tunnel at station $27+210$

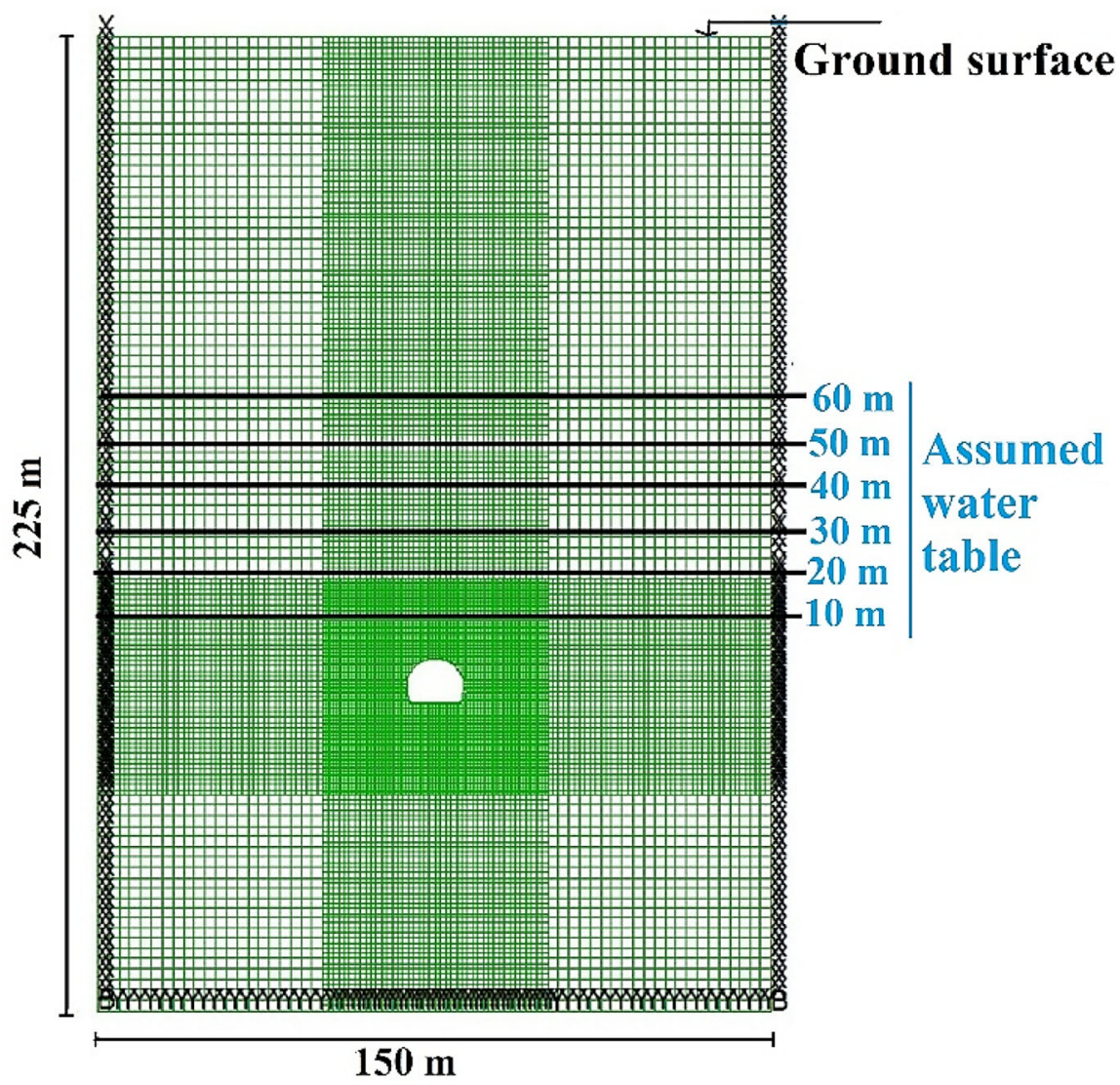

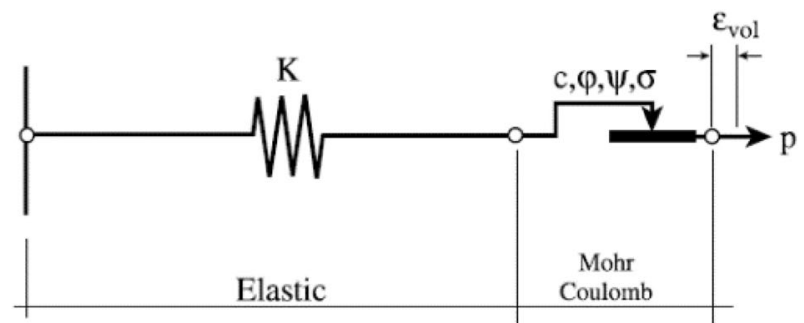

(a)

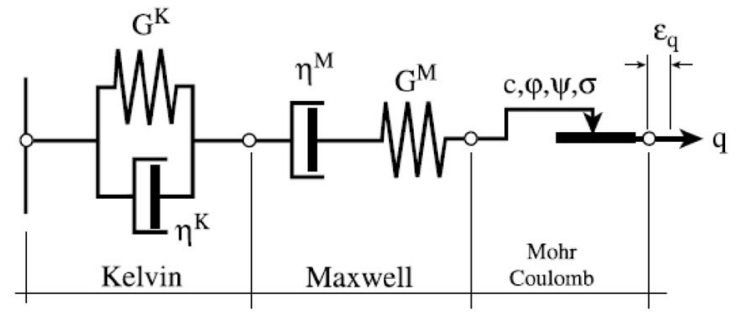

(b)

Fig. 6 Schematic representation of volumetric behavior (a) and deviatoric behavior (b) of the CVISC model

In the CVISC model, the visco-elastic strains are deviatoric and dependent on the deviatoric stress $S_{i j}$, according to the chosen flow rule, the plastic strains are deviatoric and volumetric and dependent on $\sigma_{i j}$ (Itasca Consulting Group 2002).

For the CVISC model, Eq. (1) describes the deviatoric strain rate $\left(\dot{e}_{i j}\right)$. Equations $(2)-(4)$ express these three units' constitutive laws of deviatoric behavior, respectively. In addition, Eq. (5) represents the constitutive laws of volumetric behavior.

$$
\begin{aligned}
& \dot{e}_{i j}=\dot{e}_{i j}^{K}+\dot{e}_{i j}^{M}+\dot{e}_{i j}^{P} \\
& S_{i j}=2 \eta^{K} \dot{e}_{i j}^{K}+2 G^{K} \dot{e}_{i j}^{K}
\end{aligned}
$$


$\dot{e}_{i j}^{M}=\frac{\dot{S}_{i j}}{2 G^{M}}+\frac{S_{i j}}{2 \eta^{M}}$

$\dot{e}_{i j}^{P}=\lambda^{*} \frac{\partial g}{\partial \sigma_{i j}}-\frac{1}{3} \dot{e}_{v o l}^{P} \delta_{i j}$ with $\dot{e}_{v o l}^{P}$

$=\lambda^{*}\left[\frac{\partial g}{\partial \sigma_{11}}+\frac{\partial g}{\partial \sigma_{22}}+\frac{\partial g}{\partial \sigma_{33}}\right]$

$\dot{\sigma}_{0}=K\left(\dot{e}_{v o l}-\dot{e}_{v o l}^{P}\right)$

where $\dot{e}_{i j}^{K}$ is the Kelvin strain rate, $\dot{e}_{i j}^{M}$ is Maxwell strain rate, $\dot{e}_{i j}^{P}$ is Plastic strain rates, $\eta^{K}$ is Kelvin viscosity, $G^{K}$ is Kelvin shear modulus, $\eta^{M}$ is Maxwell viscosity, $G^{M}$ is Kelvin shear modulus, $\sigma_{0}$ and $e_{v o l}$ are volumetric components of the stress and strain tensors, $\lambda^{*}$ is a multiplier that can be removed from the calculation later. For the MC unit, the plastic potential $g$ and failure criterion $f$ can be calculated as Eqs. (6) and (7), respectively:

$g=\sigma_{1}-\sigma_{3} \frac{1+\sin \psi}{1-\sin \psi}$

$f=\sigma_{1}-\sigma_{3} \frac{1+\sin \varphi}{1-\sin \varphi}+2 c \sqrt{\frac{1+\sin \varphi}{1-\sin \varphi}}$

where $\sigma_{1}$ and $\sigma_{3}$ refer to the major and minor principal stresses, $\varphi$ is friction angle, $c$ is cohesion, and $\psi$ is dilation angle of the MC model.

In this model, the Maxwell viscosity $\left(\eta^{M}\right)$ and Kelvin viscosity $\left(\eta^{K}\right)$ could be illustrated by purely viscous dampers. For the Maxwell part, an elastic element occurs instantly, similar to a spring, and relaxes immediately when the pressure is released. The viscous component of Maxwell expands when the stress is applied over time. A solid undergoing reversible viscoelastic strain is represented by the Kelvin component. When the material is subjected to constant stress, it deforms at a decreasing rate and reaches the steady-state strain asymptotically. The material relaxes and returns to its original shape by removing the stress.

For this model, the frictional slider predicts the instantaneous plastic deformation, yielding, and permanent strain rates in the accelerated creep phase. Furthermore, the anticipated plastic strains in this stage are strongly dependent on stress rather and not on time (Kabwe et al. 2020b). In fact, for the CVISC model, the plastic slider is independent of time because it is not attached to a viscous dashpot. As a result, plastic yielding in the tertiary creep stage captured using this model depends only on stress.

\subsection{The time-step for creep modeling}

In FLAC software, the time is the main discrepancy between time-independent and creep constitutive models. In creep modeling, the time-step indicates real time, but in static calculations, the time-step is employed as a virtual amount for stepping steady-state condition (Sharifzadeh et al. 2013; Itasca Consulting Group 2002). The default value for the time-step in FLAC software is zero, where the software considers the material as the linearly elastic (viscoelastic models) or the elasto-plastic (viscoplastic models) based on the circumstances. The zero value of timestep could be utilized to achieve equilibrium prior to commencing a creep modeling. Because the constitutive rules use the time-step in their calculations, it affects the modeling response. Suppose you want a system to stay in mechanical equilibrium all of the time (as in a creep analysis). In that case, the timedependent stress variations created by the constitutive law need to be small compared to the strain-dependent stress variations. In other respects, out-of-balance forces will be significant, and inertial effects may influence the solution.

A particular study of the time-step is required to ensure the creep modeling's stability. For creep analysis, it is essential to select an appropriate timestep because the constitutive laws employ it in the formulas, and it can influence the modeling's response. The maximum creep time-step for the CVISC model is determined as Eq. (8):

$\Delta t_{\max }^{c r}=\min \left(\frac{\eta^{K}}{G^{K}}, \frac{\eta^{M}}{G^{M}}\right)$

\subsection{Sequential excavation of the tunnel and underground water modeling}

In this research, the effect of underground water is examined under the varying groundwater level. The underground water tables are assumed to fluctuate between 10 and $60 \mathrm{~m}$ above the tunnel's crown (Fig. 5). In this model, acceptable hydraulic boundary conditions are also specified. The top of the model was 
considered the seepage boundary, so the water pressure at this boundary is zero. The model's bottom, right, and left sides are fixed as impermeable boundaries. It is also assumed that the head of water is constant, and the water flow is stable.

For the sequential excavation modeling, constructing the tunnel's top-heading and the bench was carried out by relaxing 70 percent of initial stress. The shotcrete and rock bolts are installed as a temporary support system, the tunnel is advanced to provide complete relaxation and pressure increases on the primary support. It is significant to mention that the shotcrete is adequately permeable to create minimal resistance to water movement when the studied water level is returned. After that, a final concrete lining is placed. A waterproof plastic membrane protects the concrete lining; the combination of concrete and membrane is not permeable.

After installing the final lining, the water level is increased to a different table above the tunnel crown. This simulation stage is done in two phases. First, to determine the pore-pressure distribution, a flow-only analysis was conducted. Then, because of the water pressure acting on the lining, a mechanical-only measurement was carried out to assess the loading and stress change in the lining.

\section{Back analysis}

This investigation used a displacement-based direct back analysis with a univariate optimization method. Back analysis techniques are now widely used as a helpful tool for detecting the rock mass's uncertain parameters, geometric systems, and initial-boundary conditions in geotechnical engineering problems with the assistance of deformation, stress, and strain monitoring through the construction of underground spaces. In general, there are two types of back analysis solutions: inverse and direct (Sharifzadeh et al. 2012). The direct method utilizes the trial quantities of uncertain variables as input data for the stress analysis algorithm, minimizing the discrepancy between measured and computed results. For complicated constitutive models, the direct back analysis is adaptable and practical. Following remarks are essential to choosing to perform a back analysis (Oreste 2005): (a) A computation model capable of evaluating the stress and strain in the rocks and analyzing the construction procedures.

(b) A practical algorithm for decreasing the error between the numerical modeling results and the observed in situ measurements.

(c) The error function.

In this research, the error function defined by Eq. (9) was employed to minimize the discrepancy between measured and computed deformations.

$\varepsilon(p)=\sqrt{\frac{1}{n} \sum_{i=1}^{n}\left(\frac{u_{i}^{m}(p)-u_{i}}{u_{i}}\right)^{2}}$

where $u_{i}$ and $u_{i}^{m}, \mathrm{i}=1,2, \ldots, \mathrm{n}$ are the measurement data and corresponding computed values, respectively. In order to reduce the influence of measurement errors, a normalized error function is employed. It should be mentioned that the lost displacements were considered and updated in the modeling results because of the delay in the installation of the instruments. After that, the modeling results were evaluated to correct the measured data.

Table 3 illustrates the final back analysis results for the parameters of the CVISC model and initial stresses ratio $(\mathrm{K})$ at station $27+210$. Figure 7 compares the modeled and measured findings at various times. In fact, numerical modeling results agree well with measured displacements using back analysis results.

\section{Long-term stability assessment of tunnel lining}

The creep behavior of rock mass and supposed underground water at different tables have been modeled during the tunnel service life. Support capability diagrams were used to evaluate the stress generated on the final lining due to rock mass creep behavior and underground water (Chen et al. 2019). In the capacity diagram, the axial force-bending moment interaction ( $\mathrm{N}-\mathrm{M}$ interaction) diagram graphically represents the induced axial force and bending moment at the tunnel lining with the failure envelope. An axial-shear force interaction diagram shows the presentation of axial and shear forces on a tunnel lining, as well as the corresponding failure zone. Table 4 illustrates the limiting formula for creating an axial force-bending moment and axial-shear force 
Table 3 Final back analysis results

\begin{tabular}{llllllll}
\hline $\mathrm{C}(\mathrm{MPa})$ & $\varphi\left(^{\circ}\right)$ & $\mathrm{E}(\mathrm{GPa})$ & $\mathrm{G}^{\mathrm{M}}(\mathrm{GPa})$ & $\mathrm{G}^{\mathrm{K}}(\mathrm{GPa})$ & $\mathrm{K}$ & $\eta^{\mathrm{M}}($ Pa.year $)$ & $\eta^{\mathrm{K}}(\mathrm{Pa}$. year $)$ \\
\hline $0.28 \pm 0.05$ & $27.5 \pm 0.5$ & $1.53 \pm 0.05$ & 0.84 & $0.71 \pm 0.025$ & 0.79 & $(1.35 \pm 0.35) \mathrm{e} 10$ & $(2.8 \pm 0.7) \mathrm{e} 8$ \\
\hline
\end{tabular}

Fig. 7 The comparison of measured and modeled convergences versus time at station $27+210$

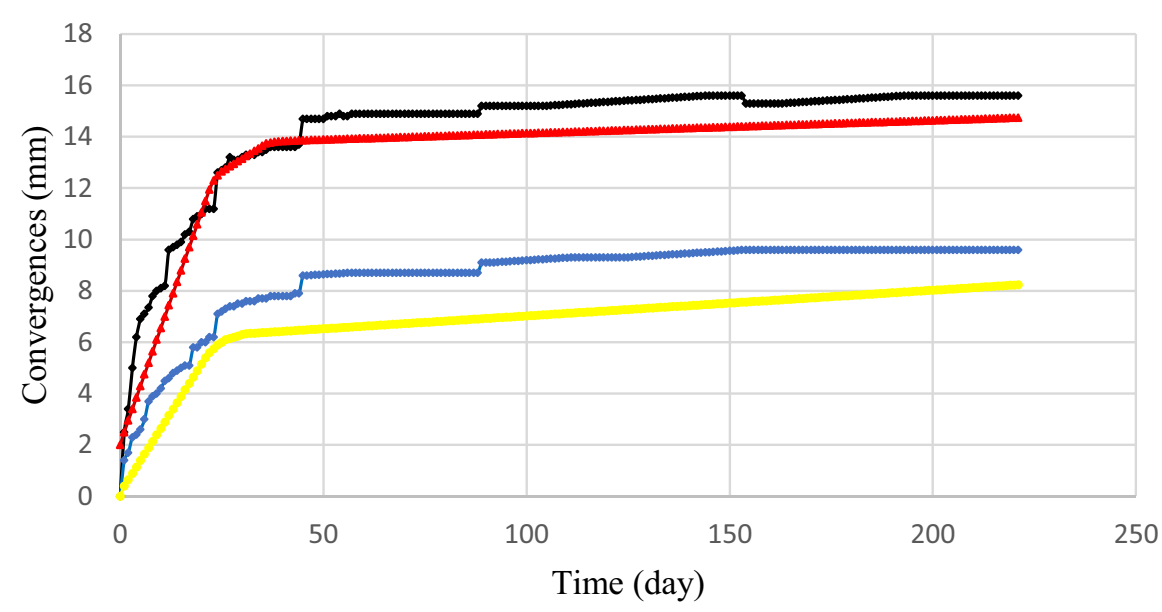

$\longrightarrow$ Measurement: L1-R1
$\longrightarrow$ Measurement: C-R1
$\longrightarrow$ Computed Value: L1-R1
$\longrightarrow$ Computed Value: C-R1

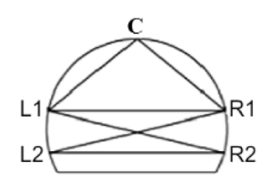

Table 4 The limiting formula for the creation of capability diagrams

\begin{tabular}{lll}
\hline $\begin{array}{l}\text { Thrust-bending moment } \\
\text { interaction }\end{array}$ & $\begin{array}{l}N=-\frac{|M| A t}{2 I}+\frac{\sigma_{c} A}{F S} \\
N=\frac{|M| A t}{2 I}+\frac{\sigma_{t} A}{F S}\end{array}$ & $\begin{array}{l}\text { The axial force limitation value }(N) \text { for compression results } \\
\text { The axial force limitation value }(N) \text { for tension results }\end{array}$ \\
& $\begin{array}{l}M_{c r}= \pm \frac{I}{t} \frac{\sigma_{c}-\sigma_{t}}{F S} \\
\text { Thrust-shear force interaction }\end{array}$ & $\begin{array}{c}\text { The critical values of bending moment }\left(M_{c r}\right) \text { for both failure in compression } \\
\text { and tension }\end{array}$ \\
& $N=\frac{\sigma_{c} A}{F S}-\frac{9}{4} \frac{Q^{2} F S}{\sigma_{c} A}$ & $\begin{array}{c}\text { The axial force limitation value }(N) \text { for compression results } \\
N=\frac{\sigma_{t} A}{F S}-\frac{9}{4} \frac{Q^{2} F S}{\sigma_{t} A}\end{array}$ \\
& $\begin{array}{c}\text { The axial force limitation value }(N) \text { for tension results } \\
Q_{c r}= \pm \frac{A}{F S} \sqrt{-\frac{4}{9} \sigma_{c} \sigma_{t}}\end{array} \quad \begin{array}{c}\text { The critical values of shear force }\left(Q_{c r}\right) \text { for both failure in compression and } \\
\text { tension }\end{array}$ \\
\hline
\end{tabular}

interaction diagram (Carranza-Torres and Diederichs, 2009).

In Table 4, FS is a factor of safety, $\sigma_{c}$ is maximum compressive stress and $\sigma_{t}$ is maximum tensile stress. In our research, it is supposed that the permanent lining behavior is elastic. By long-term analysis of tunnel behavior, it is recognized that the axial force-bending moment interaction is more critical in this case study. The axial force and bending moment values are obtained by passing the time and fluctuating water. Tables 5 and 6 show numerical analysis results for different water tables and times corresponding to the tunnel crown and spring-line, respectively. In addition, Fig. 8 illustrates the N-M interaction diagram at the tunnel's crown where the water table is $40 \mathrm{~m}$ above the tunnel crown. Figure 9 
Table 5 Induced axial force ( $\mathrm{N}$ with the unit of $\mathrm{MN}$ ) and bending moment ( $\mathrm{M}$ with the unit of MN.m) at tunnel crown for different water levels and times

\begin{tabular}{|c|c|c|c|c|c|c|c|c|c|c|c|c|}
\hline \multirow{2}{*}{$\begin{array}{l}\text { Water level (meters) } \rightarrow \\
\text { Time (years) } \downarrow\end{array}$} & \multicolumn{2}{|l|}{10} & \multicolumn{2}{|l|}{20} & \multicolumn{2}{|l|}{30} & \multicolumn{2}{|l|}{40} & \multicolumn{2}{|l|}{50} & \multicolumn{2}{|l|}{60} \\
\hline & $\mathrm{N}$ & M & $\mathrm{N}$ & M & $\mathrm{N}$ & $\mathrm{M}$ & $\mathrm{N}$ & $\mathrm{M}$ & $\mathrm{N}$ & M & $\mathrm{N}$ & M \\
\hline 10 & 1.4 & 0.04 & 1.95 & 0.04 & 2.44 & 0.048 & 3.11 & 0.055 & 3.67 & 0.064 & 4.22 & 0.073 \\
\hline 20 & 2.6 & 0.045 & 3.15 & 0.053 & 3.64 & 0.059 & 4.31 & 0.073 & 4.87 & 0.84 & 5.42 & 0.941 \\
\hline 30 & 3.5 & 0.051 & 4.05 & 0.075 & 4.54 & 0.08 & 5.21 & 0.11 & 5.77 & 0.125 & 6.32 & 0.132 \\
\hline 40 & 4.3 & 0.07 & 4.85 & 0.081 & 5.34 & 0.9 & 6.01 & 0.135 & 6.57 & 0.141 & 7.12 & 0.153 \\
\hline 50 & 5.2 & 0.09 & 5.75 & 0.101 & 6.24 & 0.11 & 6.91 & 0.147 & 7.47 & 0.154 & 8.02 & 0.167 \\
\hline 60 & 5.7 & 0.1 & 6.25 & 0.11 & 6.74 & 0.122 & 7.41 & 0.161 & 7.97 & 0.17 & 8.52 & 0.183 \\
\hline 70 & 6.4 & 0.11 & 6.95 & 0.121 & 7.44 & 0.143 & 8.11 & 0.182 & 8.67 & 0.2 & 9.22 & 0.212 \\
\hline 80 & 6.6 & 0.13 & 7.15 & 0.135 & 7.64 & 0.165 & 8.31 & 0.22 & 8.87 & 0.23 & 9.42 & 0.251 \\
\hline 90 & 7 & 0.155 & 7.55 & 0.162 & 8.04 & 0.21 & 8.71 & 0.245 & 9.27 & 0.26 & 9.82 & 0.278 \\
\hline 100 & 7.4 & 0.16 & 7.95 & 0.17 & 8.4 & 0.22 & 9.11 & 0.285 & 9.67 & 0.3 & 10.22 & 0.32 \\
\hline
\end{tabular}

Table 6 Induced axial force ( $\mathrm{N}$ with the unit of $\mathrm{MN}$ ) and bending moment ( $\mathrm{M}$ with the unit of MN.m) at tunnel spring-line for different water levels and times

\begin{tabular}{|c|c|c|c|c|c|c|c|c|c|c|c|c|}
\hline \multirow{2}{*}{$\begin{array}{l}\text { Water level (meters) } \rightarrow \\
\text { Time (years) } \downarrow\end{array}$} & \multicolumn{2}{|l|}{10} & \multicolumn{2}{|l|}{20} & \multicolumn{2}{|l|}{30} & \multicolumn{2}{|l|}{40} & \multicolumn{2}{|l|}{50} & \multicolumn{2}{|l|}{60} \\
\hline & $\mathrm{N}$ & $\mathrm{M}$ & $\mathrm{N}$ & M & $\mathrm{N}$ & M & $\mathrm{N}$ & M & $\mathrm{N}$ & M & $\mathrm{N}$ & M \\
\hline 10 & 1.5 & 0.08 & 1.63 & 0.084 & 1.85 & 0.086 & 2.05 & 0.09 & 2.35 & 0.091 & 2.8 & 0.099 \\
\hline 20 & 3 & 0.1 & 3.13 & 0.11 & 3.35 & 0.12 & 3.55 & 0.13 & 3.85 & 0.141 & 4.3 & 0.15 \\
\hline 30 & 4.1 & 0.14 & 4.23 & 0.142 & 4.45 & 0.151 & 4.65 & 0.166 & 4.95 & 0.178 & 5.4 & 0.188 \\
\hline 40 & 5 & 0.2 & 5.13 & 0.215 & 5.35 & 0.234 & 5.55 & 0.251 & 5.85 & 0.259 & 6.3 & 0.269 \\
\hline 50 & 5.9 & 0.25 & 6.03 & 0.265 & 6.25 & 0.286 & 6.45 & 0.305 & 6.75 & 0.311 & 7.2 & 0.322 \\
\hline 60 & 6.8 & 0.29 & 6.93 & 0.31 & 7.15 & 0.325 & 7.35 & 0.341 & 7.65 & 0.348 & 8.1 & 0.356 \\
\hline 70 & 7 & 0.32 & 7.23 & 0.35 & 7.45 & 0.375 & 7.65 & 0.39 & 7.95 & 0.405 & 8.4 & 0.411 \\
\hline 80 & 7.6 & 0.38 & 7.73 & 0.405 & 7.95 & 0.424 & 8.15 & 0.45 & 8.45 & 0.462 & 8.9 & 0.473 \\
\hline 90 & 8.1 & 0.4 & 8.23 & 0.43 & 8.45 & 0.456 & 8.65 & 0.479 & 8.95 & 0.50 & 9.4 & 0.51 \\
\hline 100 & 8.3 & 0.44 & 8.43 & 0.46 & 8.65 & 0.486 & 8.85 & 0.505 & 9.15 & 0.52 & 9.6 & 0.53 \\
\hline
\end{tabular}

also shows the N-M interaction diagram at the tunnel's spring-line, where the water table is $10 \mathrm{~m}$ above the tunnel crown. Simulation results show that induced stresses can rise significantly over time for the crown and spring-line of the permanent lining.

As shown in Fig. 9 and Table 6, for the tunnel spring-line, after 70 years and in the case of water table $10 \mathrm{~m}$, concrete's compressive strengths would not sustain the pressures generated by the axial force and the bending moment. Table 6 represents that by increasing the underground water table, the stability time of tunnel lining decreases. In the tunnel crown, the lining is stable until the supposed underground water table becomes $40 \mathrm{~m}$ above the tunnel crown. In this case (Fig. 8), after 86 years, concrete's compressive strengths are insufficient to sustain the pressures created by the creep behavior of rock and underground water.

Figure 10 represents the effect of fluctuating water tables on the stability time at the tunnel spring-line. As shown in Fig. 10, the increasing water table decreases the stability time of tunnel lining. The results show that when the water table is $10 \mathrm{~m}$, the tunnel's springline stability time is 70 years and when the water 
Fig. 8 N-M interaction diagram at the tunnel lining crown when the water level is $40 \mathrm{~m}$
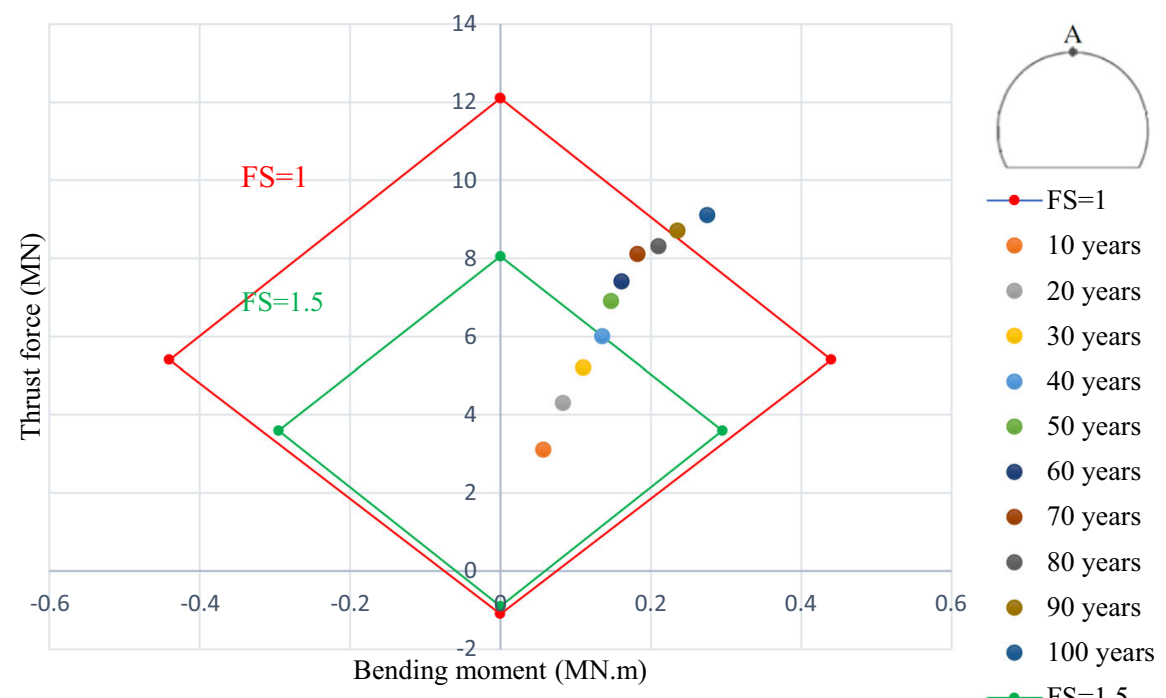

Fig. 9 N-M interaction diagram at the tunnel lining spring-line when the water level is $10 \mathrm{~m}$

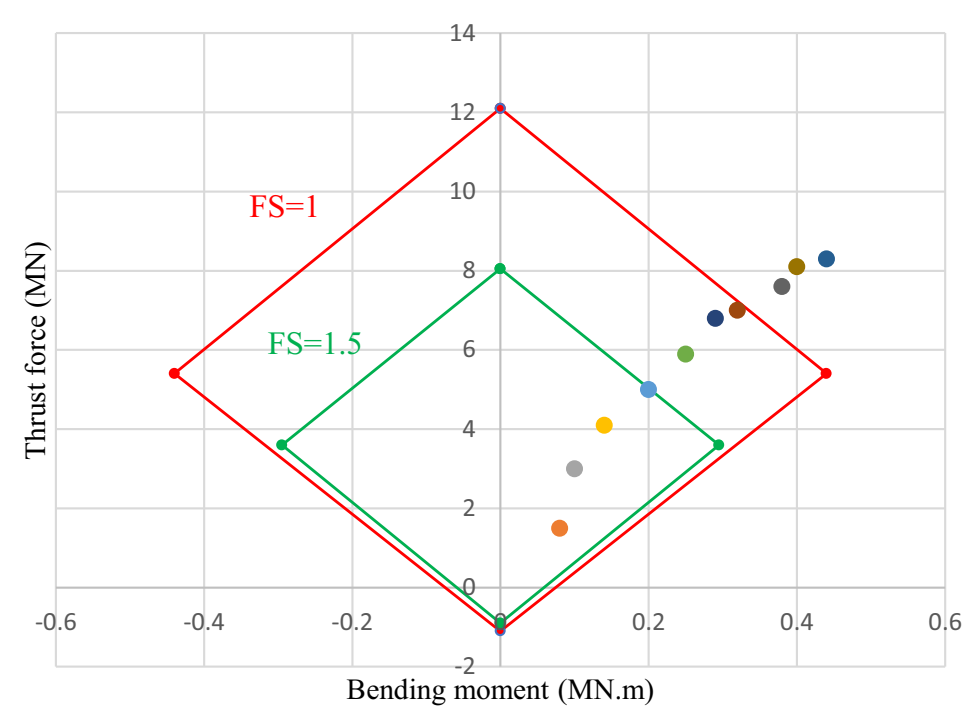

table increase to $30 \mathrm{~m}$, the time of stability decreases to 60 years, and similarly, for the water level $60 \mathrm{~m}$, the time of stability decrease to 50 years.

Figure 11 shows that the increasing water table significantly affects thrust force and bending moment at the tunnel's spring-line. For instance, for the specific tunnel life, for example, 60 years, numerical results show that tunnel lining is stable until the water table increases to $30 \mathrm{~m}$ above the tunnel crown. After this level, the concrete's compressive strengths will not withstand the pressures caused by the rising water table.

\section{Discussion}

The time-dependent deformation of tunnels and rock masses has been studied in detail for many years (Sulem et al. 1987). The behavior analysis is usually based on numerical modeling (Zhang et al. 2020a, 2020b), in situ measurements (Kovačević et al. 2021; Selen et al. 2019), or laboratory testing of deformation (Liu et al. 2021). The deformation of weak rocks is often linked to water and is especially critical when clay minerals are present (Jia et al. 2018; Lyu et al. 2017). In our back analysis approach, the monitored deformation patterns were compared with 
Fig. 10 N-M interaction diagram at the tunnel's lining spring-line for the different water tables and tunnel life

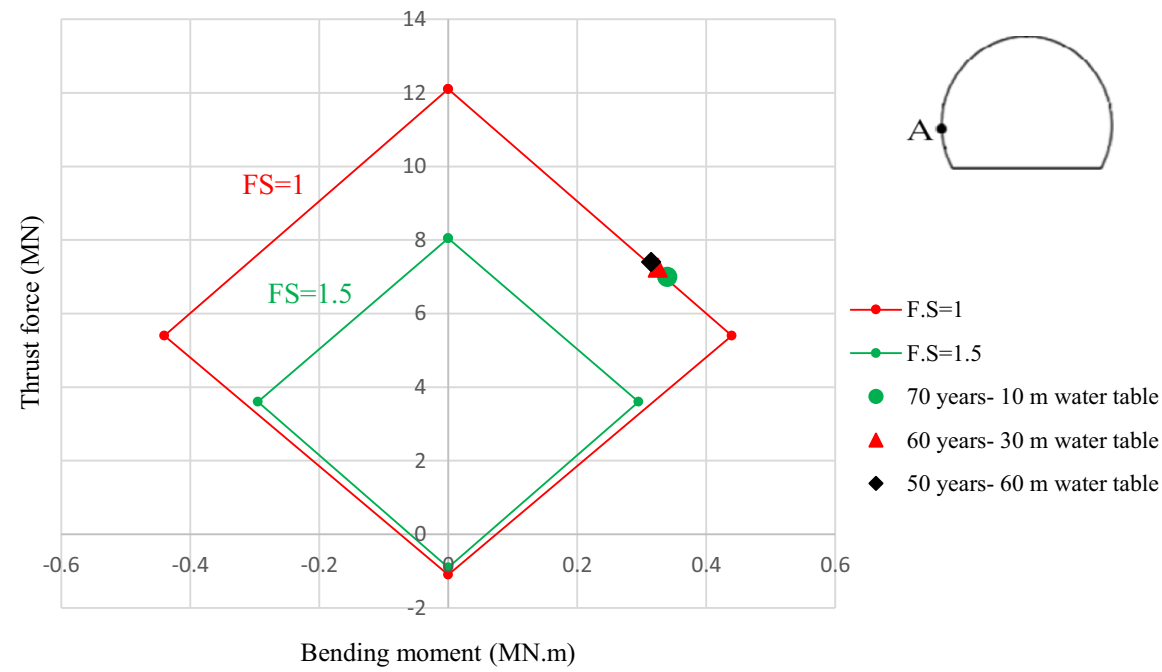

Fig. $11 \mathrm{~N}-\mathrm{M}$ interaction diagram at the tunnel lining spring-line when the water level fluctuates

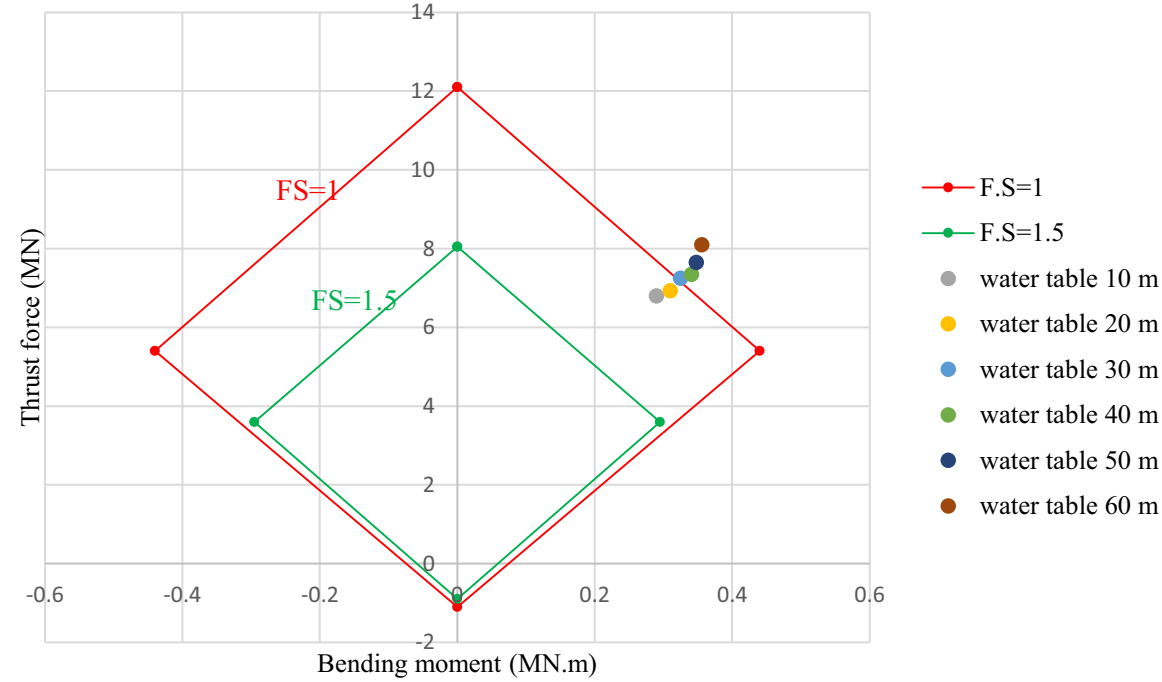

numerical simulations. Our back analysis technique with numerical modeling showed good agreement with the monitored displacements (Fig. 7). Kovačević et al. (2021) also demonstrated that the in-situ monitoring data could be a valuable technique to determine rock mass time-dependent properties. Our findings indicate that tunnels constructed in the weak rock mass, especially for the faults zone, the tunnel lining's stresses rise considerably with time and fluctuating underground water. It is in good agreement with previous works, where time-dependent changes in viscoelastic rock masses and the interaction of liners were studied (Do et al. 2020). The introduction of underground water strongly modifies the system's stability, especially when weak rocks are present (Zhou et al. 2014). In our study, the tunnel crown is stable in the case of rock mass creep behavior, but by introducing underground water and in the case of water table equals $40 \mathrm{~m}$, the pressures created by axial force and bending moment are too considerable for the tunnel crown to sustain (Table 5 and Fig. 8). In this condition, the creep behavior of rocks and underground water need to be investigated for the tunnels' long-term stability analysis (Xu et al. 2020). Tables 5 and 6 indicate that the tunnel's spring-line stresses are larger than the tunnel's crown. Furthermore, displacement measurements and numerical modeling (Fig. 7) show that displacement at the spring-line is more 
remarkable than the crown. These differences are mainly because of the anisotropic in-situ initial stresses and the tunnel shape. Xu et al. (2019) also showed that due to the creep behavior of the Dujia tunnel's host rocks, the cracks appeared earlier at the tunnel spring-line than the tunnel crown. The longterm analysis of the Shibli tunnel's final lining indicates that by passing time, the bending moment in the tunnel spring-line is more increased than the bending moment in the tunnel crown. It illustrates that besides the time-dependent behavior of rocks, the initial in-situ stress and the tunnel shape also influence the long-term induced stress in tunnel lining. Figures 10 and 11 indicate that the presence of underground water affects the long-term stability of the tunnel. For this case study, the increasing $10 \mathrm{~m}$ in the water table approximately decreases five years of tunnel lining stability time.

\section{Conclusions}

The Shibli tunnel's time-dependent behavior was examined by the finite-difference method. The creep behavior of rock mass and underground water effects were analyzed to study the time-dependent stability of the tunnel lining. This research shows that the creep behavior of weak rocks and underground water significantly influence the long-term behavior of tunnel lining. Direct back analysis with a univariate optimization algorithm was used, and the CVISC model's properties and initial stresses ratio were obtained. The comparison of measured and calculated results demonstrates that the back analysis techniques could adopt rock mass creep properties successfully. The effect of underground water was analyzed for the different groundwater tables, and long-term stability analyses of tunnel lining were conducted. The main findings of this study are as follows:

- The stress distribution in the tunnel lining varies over time in response to the creep behavior of rocks and fluctuating subsurface water table. For the tunnel spring-line, after 70 years and, in the case of water table $10 \mathrm{~m}$, concrete's compressive strengths will not sustain the pressures caused by induced axial force and bending moment and increasing water table. In addition, the critical stability time and water table for tunnel crown are 86 years and $40 \mathrm{~m}$, respectively.

- Simulation results indicate that the tunnel's springline stresses are larger than the tunnel crown. The average bending moment for the tunnel's springline is 2.5 times of the bending moment at the tunnel's crown during the tunnel service life.

- Underground water decreases the time of stability of tunnel lining. The numerical modeling results reveal that the increasing $20 \mathrm{~m}$ in the water table approximately decreases ten years of tunnel lining stability time.

- Increases in the water table have a more significant impact on the induced axial forces than on the bending moment. The axial force rises approximately 13 percent for the tunnel spring-line by increasing $10 \mathrm{~m}$ in the water table.

- Induced tunnel lining stresses in the tunnel springline are higher than the tunnel crown. The reason is probably related to the initial stresses and the shape of the tunnel.

- According to the current research, it is highly recommended that the time-dependent properties of rocks are considered in the long-term maintenance of the underground spaces constructed in the weak rock mass.

Funding Open access funding provided by Budapest University of Technology and Economics.

\section{Declarations}

Conflict of interest On behalf of all authors, the corresponding author states that there is no conflict of interest.

Open Access This article is licensed under a Creative Commons Attribution 4.0 International License, which permits use, sharing, adaptation, distribution and reproduction in any medium or format, as long as you give appropriate credit to the original author(s) and the source, provide a link to the Creative Commons licence, and indicate if changes were made. The images or other third party material in this article are included in the article's Creative Commons licence, unless indicated otherwise in a credit line to the material. If material is not included in the article's Creative Commons licence and your intended use is not permitted by statutory regulation or exceeds the permitted use, you will need to obtain permission directly from the copyright holder. To view a copy of this licence, visit http://creativecommons.org/licenses/by/4.0/. 


\section{References}

Aradan Construction Co (2009) Report on geology and engineering geology of Shibli tunnels P350. Aradan Construction Company, Tabriz

Bérest P, Gharbi H, Brouard B, Brückner D, DeVries K, Hévin G, Urai J (2019) Very slow creep tests on salt samples. Rock Mech Rock Eng 9:1-18. https://doi.org/10.1007/ s00603-019-01778-9

Carranza-Torres C, Diederichs M (2009) Mechanical analysis of circular liners with particular reference to composite supports. For example, liners consisting of shotcrete and steel sets. Tunn Undergr Space Technol 24:506-532. https://doi. org/10.1016/j.tust.2009.02.001

Chen F, Wang L, Zhang W (2019) Reliability assessment on stability of tunneling perpendicularly beneath an existing tunnel considering spatial variabilities of rock mass properties. Tunn Undergr Space Technol 88:276-289. https:// doi.org/10.1016/j.tust.2019.03.013

Do D, Tran N, Mai V, Hoxha D, Vu M (2020) Time-dependent reliability analysis of deep tunnel in the viscoelastic burger rock with sequential installation of liners. Rock Mech Rock Eng 53:1259-1285. https://doi.org/10.1007/s00603-01901975-6

Grgic D, Homand F, Hoxha D (2003) A short- and long-term rheological model to understand the collapses of iron mines in Lorraine, France. Comput Geotech 30:557-570. https:// doi.org/10.1016/S0266-352X(03)00074-0

Günther R, Salzer K, Popp T, Lüdeling C (2015) Steady-state creep of rock salt: improved approaches for lab determination and modelling. Rock Mech Rock Eng 48:2603-2613. https://doi.org/10.1007/s00603-015-08392

Guo H, He M, Sun C, Li B, Zhang F (2012) Hydrophilic and strength-softening characteristics of calcareous shale in deep mines. J Rock Mech Geotech Eng 4:344-351. https:// doi.org/10.3724/SP.J.1235.2012.00344

Haifeng L, Zhigen Z (2016) Creep properties and a creep equation of delay outburst coal and its adjacent mudstone. Int J Min Sci Technol 26:1161-1167. https://doi.org/10. 1016/j.ijmst.2016.09.027

Hoxha D, Homand F, Auvray C (2006) Deformation of natural gypsum rock: mechanisms and questions. Eng Geol 86:1-17. https://doi.org/10.1016/j.enggeo.2006.04.002

Itasca Consulting Group (2002) FLAC Fast Lagrangian Analysis Continua Manual. Itasca Consulting Group Inc., Minneapolis

Jia S, Zhang L, Wu B, Yu H, Shu J (2018) A coupled hydromechanical creep damage model for clayey rock and its application to nuclear waste repository. Tunn Undergr Space Technol 74:230-246. https://doi.org/10.1016/j.tust. 2018.01.026

Jia S, Wen C, Wu B (2020) A nonlinear elasto-viscoplastic model for clayed rock and its application to stability analysis of nuclear waste repository. Energy Sci Eng 8:150-165. https://doi.org/10.1002/ese3.515

Kabwe E, Karakus M, Chanda E (2020a) Creep constitutive model considering the overstress theory with an associative viscoplastic flow rule. Comput Geotech 124:103629. https://doi.org/10.1016/j.compgeo.2020.103629
Kabwe E, Karakus M, Chanda E (2020b) Isotropic damage constitutive model for time-dependent behavior of tunnels in squeezing ground. Comput Geotech 127:103738. https:// doi.org/10.1016/j.compgeo.2020.103738

Kovačević MS, Bačić M, Gavin K, Stipanović I (2021) Assessment of long-term deformation of a tunnel in soft rock by utilizing particle swarm optimized neural network. Tunn Undergr Space Technol 110:103838. https://doi.org/ 10.1016/j.tust.2021.103838

Li Z, Liu S, Ren W, Fang J, Zhu Q, Dun Z (2020) Multiscale laboratory study and numerical analysis of water-weakening effect on shale. Adv Mater Sci Eng 2020:5263431. https://doi.org/10.1155/2020/5263431

Liu J, Wu F, Zou Q, Chen J, Ren S, Zhang C (2021) A variableorder fractional derivative creep constitutive model of salt rock based on the damage effect. Geomech Geophys GeoEnergy Geo-Resour 7:46. https://doi.org/10.1007/s40948021-00241-w

Lyu Q, Long X, Ranjith PG, Tan J, Kang Y (2017) Experimental investigation on the mechanical behaviours of a low-clay shale under water-based fluids. Eng Geol 233:124-138. https://doi.org/10.1016/j.enggeo.2017.12.002

Miščević P, Vlastelica G (2014) Impact of weathering on slope stability in soft rock mass. J Rock Mech Geotech Eng 6:240-250. https://doi.org/10.1016/j.jrmge.2014.03.006

Oreste P (2005) Back-analysis techniques for the improvement of the understanding of rock in underground constructions. Tunn Undergr Space Technol 20:7-21. https://doi.org/10. 1016/j.tust.2004.04.002

Panthi KK, Shrestha PK (2018) Estimating tunnel strain in the weak and schistose rock mass influenced by stress anisotropy: An evaluation based on three tunnel cases from Nepal. Rock Mech Rock Eng 51:1823-1838. https://doi. org/10.1007/s00603-018-1448-7

Patil M, Choudhury D, Ranjith PG, Zhao J (2018) Behavior of shallow tunnel in soft soil under seismic conditions. Tunn Undergr Space Technol 82:30-38. https://doi.org/10.1016/ j.tust.2018.04.040

Pellet F, Hajdu A, Deleruyelle F, Besnus F (2005) A viscoplastic model including anisotropic damage for the time dependent behaviour of rock. Int J Numer Anal Meth Geomech 29:941-970. https://doi.org/10.1002/nag.450

Pellet F, Roosefid M, Deleruyelle F (2009) On the 3D numerical modelling of the time-dependent development of the damage zone around underground galleries during and after excavation. Tunn Undergr Space Technol 24:665-674. https://doi.org/10.1016/j.tust.2009.07.002

Sainoki A, Tabata S, Mitri H, Fukuda D (2017) Time-dependent tunnel deformations in homogeneous and heterogeneous weak rock formations. Comput Geotech 92:186-200. https://doi.org/10.1016/j.compgeo.2017.08.008

Schenk O, Urai J, Piazolo S (2006) Structure of grain boundaries in wet, synthetic polycrystalline, statically recrystallizing halite - evidence from cryo-SEM observations. Geofluids 6:93-104. https://doi.org/10.1111/j.1468-8123.2006. 00134.x

Selen L, Panthi K, Tunbridge L.W, Schönborn, T (2019) Field testing of weak rock deformation in water tunnels: A practical review of the flatjack test 1716-1723. Rock mechanics for natural resources and infrastructure 
development. In: ISRM 2019-14th International Congress of Rock Mechanics, Foz do Iguaçu, Brazil

Sharifzadeh M, Daraei R, Sharifi Broojerdi M (2012) Design of sequential excavation tunneling in weak rocks through findings obtained from displacements based back analysis. Tunn Undergr Space Technol 28:10-17. https://doi.org/10. 1016/j.tust.2011.08.003

Sharifzadeh M, Tarifard A, Moridi M (2013) Time-dependent behavior of tunnel lining in weak rock mass based on displacement back analysis method. Tunn Undergr Space Technol 38:348-356. https://doi.org/10.1016/j.tust.2013. 07.014

Sharifzadeh M, Tarifard A (2014) Long-term stability analysis of tunnel lining in weak rocks using data from tunnel construction. In: Proceedings of the World Tunnel Congress. Foz do Iguaçu, Brazil

Singh A, Kumar Chandan K, Gopi Kannan L, Seshagiri Rao K, Ayothiraman R (2018) Estimation of creep parameters of rock salt from uniaxial compression tests. Int $\mathrm{J}$ Rock Mech Min Sci 107:243-248. https://doi.org/10.1016/j.ijrmms. 2018.04.037

Sulem J, Panet M, Guenot A (1987) An analytical solution for time-dependent displacements in a circular tunnel. Int J Rock Mech Min Sci Geomech Abstr 24:155-164. https:// doi.org/10.1016/0148-9062(87)90523-7

Török Á, Vlastelica G, Baloevic G, Grgić N, Görög P (2019) Comparative analysis of slope stability: seismic loading and engineering geology; examples from Croatia and Hungary. In: ISRM specialised conference - geotechnical challenges in Karst, Omiš-Split Croatia

Verbovšek T, Kanduč T (2016) Isotope geochemistry of groundwater from fractured dolomite aquifers in Central Slovenia. Aquat Geochem 22:131-151. https://doi.org/10. 1007/s10498-015-9281-z

Vlastelica G, Miščević P, Cvitanović NS (2018) Durability of soft rocks in Eocene flysch formation (Dalmatia, Croatia). Eng Geol 245:207-217. https://doi.org/10.1016/j.enggeo. 2018.08.015

Wang M, Cai M (2020) A grain-based time-to-failure creep model for brittle rocks. Comput Geotech 119:103344. https://doi.org/10.1016/j.compgeo.2019.103344

Wang R, Zhuo Z, Zhou H, Liu J (2017) A fractal derivative constitutive model for three stages in granite creep. Results in Phys 7:2632-2638. https://doi.org/10.1016/j.rinp.2017. 07.051

Weng MC, Tsai LS, Liao CY, Jeng FS (2010) Numerical modeling of tunnel excavation in weak sandstone using a time-dependent anisotropic degradation model. Tunn Undergr Space Technol 25:397-406. https://doi.org/10. 1016/j.tust.2010.02.004

Xu G, Gutierrez M (2021) Study on the damage evolution in secondary tunnel lining under the combined actions of corrosion degradation of preliminary support and creep deformation of surrounding rock. Transp Geotech 27:100501. https://doi.org/10.1016/j.trgeo.2020.100501

$\mathrm{Xu}$ T, Tang C, Zhao J (2012) Modeling of rheological deformation of inhomogeneous rock and associated time-dependent response of tunnels. Int J Geomech 12:147-159. https://doi.org/10.1061/(ASCE)GM.1943-5622.0000130

Xu G, He C, Yang Q, Wang B (2019) Progressive failure process of secondary lining of a tunnel under creep effect of surrounding rock. Tunn Undergr Space Technol 90:76-98. https://doi.org/10.1016/j.tust.2019.04.024

Xu G, He C, Chen Z, Yang Q (2020) Transversely isotropic creep behavior of phyllite and its influence on the longterm safety of the secondary lining of tunnels. Eng Geol 278:105834. https://doi.org/10.1016/j.enggeo.2020. 105834

Yan B, Guo Q, Ren F, Cai M (2020) Modified Nishihara model and experimental verification of deep rock mass under the water-rock interaction. Int $J$ Rock Mech Min Sci 128:104250. https://doi.org/10.1016/j.ijrmms.2020. 104250

Yang S, Xu P, Xu T (2015) Nonlinear visco-elastic and accelerating creep model for coal under conventional triaxial compression. Geomech Geophys Geo-Energy Geo-Resour 1:109-120. https://doi.org/10.1007/s40948-015-0014-y

Yu HD, Chen WZ, Gong Z, Tan XJ, Ma YS, Li XL, Sillen X (2015) Creep behavior of boom clay. Int J Rock Mech Min Sci 76:256-264. https://doi.org/10.1016/j.ijrmms.2015.03. 009

Zhang Z, Liu X, Cheng L, Wu S (2020a) A rheological constitutive model for damaged zone evolution of a tunnel considering strain hardening and softening. Geomech Geophys Geo-Energy Geo-Resour 6:56. https://doi.org/10.1007/ s40948-020-00181-x

Zhang W, Zhang R, Wu C, Chee Goh AT, Lacasse S, Liu Z, Liu $\mathrm{H}$ (2020b) State-of the-art review of soft computing applications in underground excavations. Geosci Front 11:1095-1106. https://doi.org/10.1016/j.gsf.2019.12.003

Zhou H, Zhang C, Li Z, Hu D, Hou J (2014) Analysis of mechanical behavior of soft rocks and stability control in deep tunnels. J Rock Mech Geotech Eng 6:219-226. https://doi.org/10.1016/j.jrmge.2014.03.003

Zhu X, Yang S, Xia H, Xia Q, Guofeng Z, Wei L (2020) Joint support technology and its engineering application to deep soft rock tunnel with strong creep. Geotech Geol Eng 38:3403-3414. https://doi.org/10.1007/s10706-02001222-8

Publisher's Note Springer Nature remains neutral with regard to jurisdictional claims in published maps and institutional affiliations. 